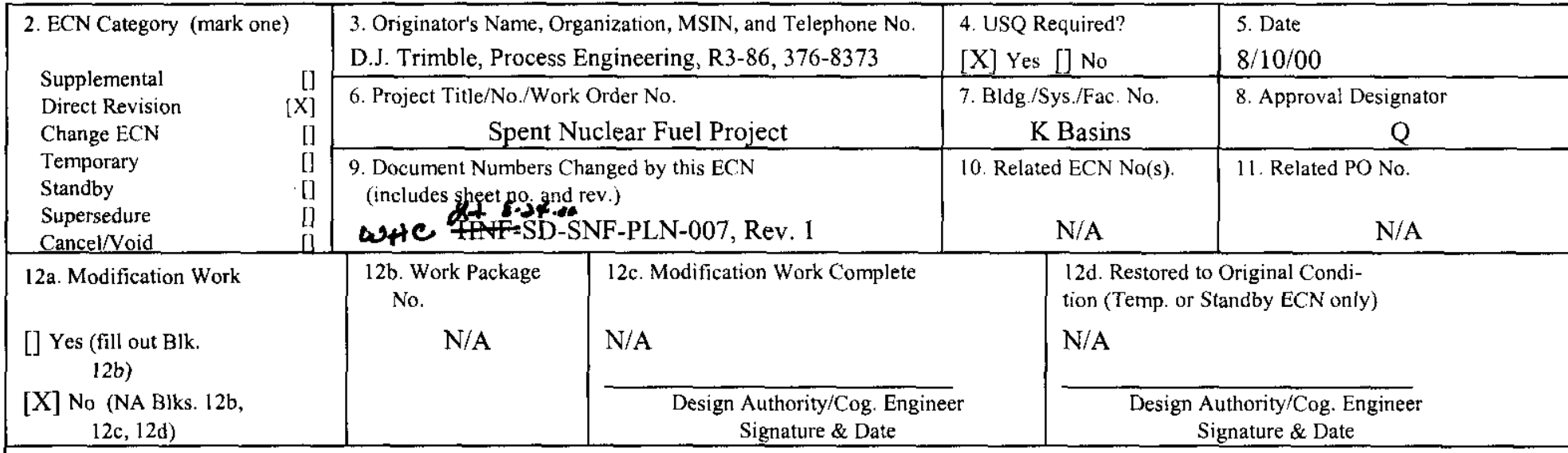

13a. Description of Change

13b. Design Baseline Document? [] Yes [X] No

This is an update to the Characterization Plan, clarifying the intent of the fuel characterization for the Spent Nuclear Fuel Project and removing requirements that became unnecessary due to changes in Project strategy.

The focus of ignition and oxidation kinetics testing was changed from providing bounding behavior to providing confirmatory data.

Requirements for hot conditioning tests and dry storage simulation testing were eliminated.

Whole-element testing was added to provide drying data for damaged fuel.

Requirements for characterization of sludge were referred to the current sampling and analysis plan for sludge testing. The OCRWM document has been reviewed in accordance with AP EN-6-009. The approval signatures of the reviewers verify acceptance of this plan based on the reviews.

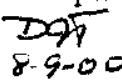

USQ Tracking No. K-00-1069

$\left.\begin{array}{l}\text { 14a. Justification (mark one) } \\ \text { Criteria Change [X] } \\ \text { Design Jmprovement } \\ \text { Environmental } \\ \text { Facility Deactivation } \\ \text { As-Found }\end{array}\right]$
Facilitate Const
Const. Error/Omission []
Design Error/Omission []

15. Distribution (include name, MSIN, and no. of copies)
R. B. Baker $\quad$ H0-40
R. C. DeKlever R3-11
J. R. Frederickson R3-86
B. J. Makenas $\quad$ H0-40
W. C. Miller R3-11
L. J. Olguin H5-24
D. W. Smith S2-48
J. A. Swenson R3-11
D. J. Trimble R3-86

\begin{abstract}
14b. Justification Details
Compliance status of the SNF Project Quality Assurance Program to the requirements of DOE/RW/0333P was the subject of a 1999 audit by the NSNF Program (Davis 1999). Corrective Action Request, CAR No. 99-NSNF-AU-044-III-002, an outcome of that audit, notes that while the intent of the characterization plan (WHC-SNF-PLN-007, Rev. 1) was to "provide bounding behavior for the fue?" and that "Documentation was not provided to detail the technical basis for the judgment that revised sampling provides adequate data to bound the condition and expected behavior for all N-Reactor SNF." This was a condition that was not in compliance with the requirements of DOE/RW/0333P, Supplement III, Section 2.1, Planning Scientific Investigations

The changes in this revision to the characterization plan provide the basis for closure of CAR No. 99-NSNF-AU-044-III-002. Approval and issue of this document is evidence that the activities and documentation of the fuel characterization provided the information and data required by the SNF Project to support the removal, drying, and storage of the K Basin fuel.
\end{abstract}

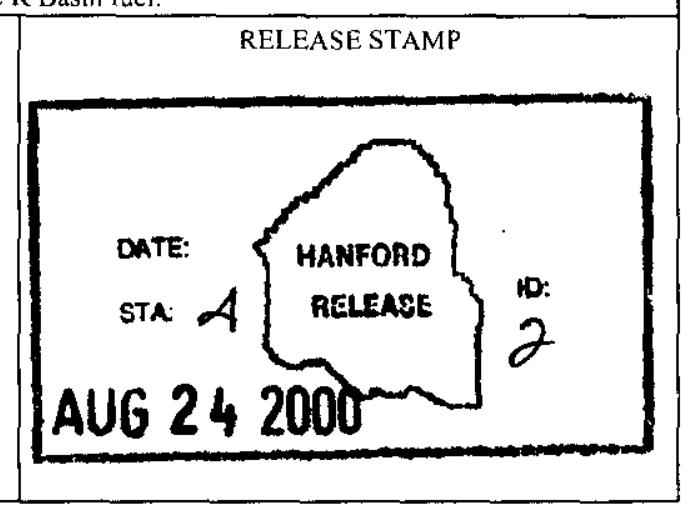

A-7900-013-2(10/97) 


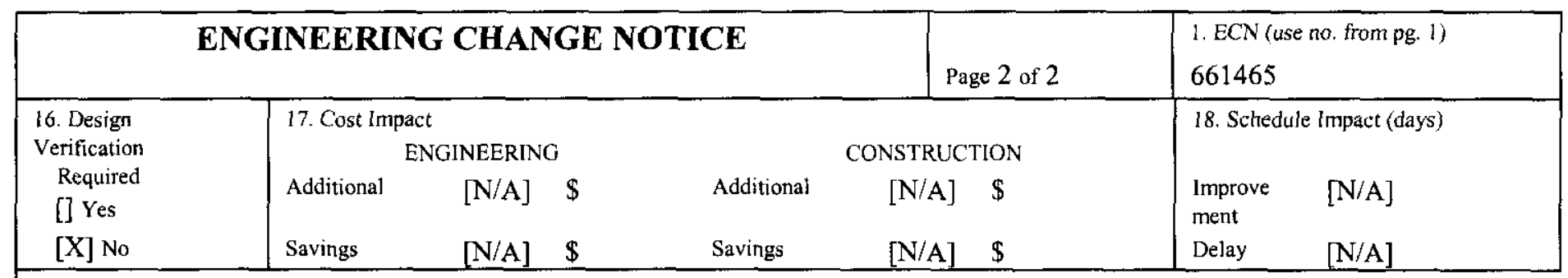

19. Change Impact Review: Indicate the related documents (other than the engineering documents identified on Side l)

that will be affected by the change described in Block 13. Enter the affected document number in Block 20.

SDD/DD

Functional Design Criteria

Operating Specification

Criticality Specification

Conceptual Design Report

Equipment Spec

Const. Spec.

Procurement Spec.

Vendor Information

OM Manual

FSAR/SAR

Safety Equipment List

Radiation Work Permit

Environmental Impact Statement

Environmental Report

Environmental Permit

Seismic/Stress Analysis
Stress/Design Report
Interface Control Drawing
Installation Procedure
Maintenance Procedure
Engineering Procedure
Operating Instruction
Operating Procedure
Operational Safety Requirement
IEFD Drawing
Cell Arrangement Drawing
Essential Material Specification
Fac. Proc. Samp. Schedule
Inspection Plan
Inventory Adjustment Request

Tank Calibration Manual

Health Physics Procedure

Spares Multiple Unit Listing

Test Procedures/Specification

Component Index

ASME Coded Item

Human Factor Consideration

Computer Software

Electric Circuit Schedule

ICRS Procedure

Process Control Manual/Plan

Process Flow Char

Purchase Requisition

Tickler File

N/A
[]

[]

[]

[]

[]

[]

[]

[]

[]

[]

[]

[]

[]

[X]

20. Other Affected Documents: (NOTE: Documents listed below will not be revised by this ECN.) Signatures below indicate that the signing organization has been notified of other affected documents listed below.

Document Number/Revision

Document Number/Revision

Document Number Revision

N/A

21. Approvals

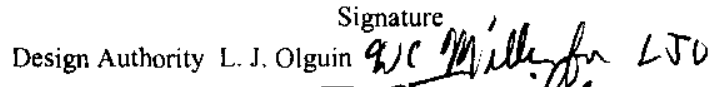

Cog. Eng. D. J. Trimble Ifre

Cog. Mgr. J. R. Frederickson th treduch

QA DW Smeth

Safety

Environ.

Other R. B. Baker $\chi b B$ a

W. C. Miller $2, C / / 1 / \mathrm{ll}$

J. A. Swenson Yorfe a Sum

Date Signature

Date

$\Phi / 15 / 00$ Design Agent

$8-9-00 \quad P E$

$\$ 19100 \quad$ QA

$8 / 14 / 00$ Safety

Design

$8 / 23 / 00 \quad$ Other

$8 / 15 / 00$

$8 / 14 / 00$
DEPARTMENT OF ENERGY

Signature or a Control Number that tracks the Approval Signature

ADDITIONAL 


\section{Plan for Characterization of K Basin Spent Nuclear Fuel and Sludge (OCRWM)}

Prepared for the U.S. Department of Energy

Assistant Secretary for Environmental Management

Project Hanford Management Contractor for the

U.S. Department of Energy under Contract DE-AC06-96RL 13200

Fluor Hanford

P.O. Box 1000

Richland, Washington 


\title{
Plan for Characterization of K Basin Spent Nuclear Fuel and Sludge (OCRWM)
}

\author{
D. J. Trimble \\ Fluor Hanford
}

Date Published

August 2000

Prepared for the U.S. Department of Energy

Assistant Secretary for Environmental Management

Project Hanford Management Contractor for the

U.S. Department of Energy under Contract DE-AC06-96RL13200

Fluor Hanford

P.O. Box 1000

Richland, Washington
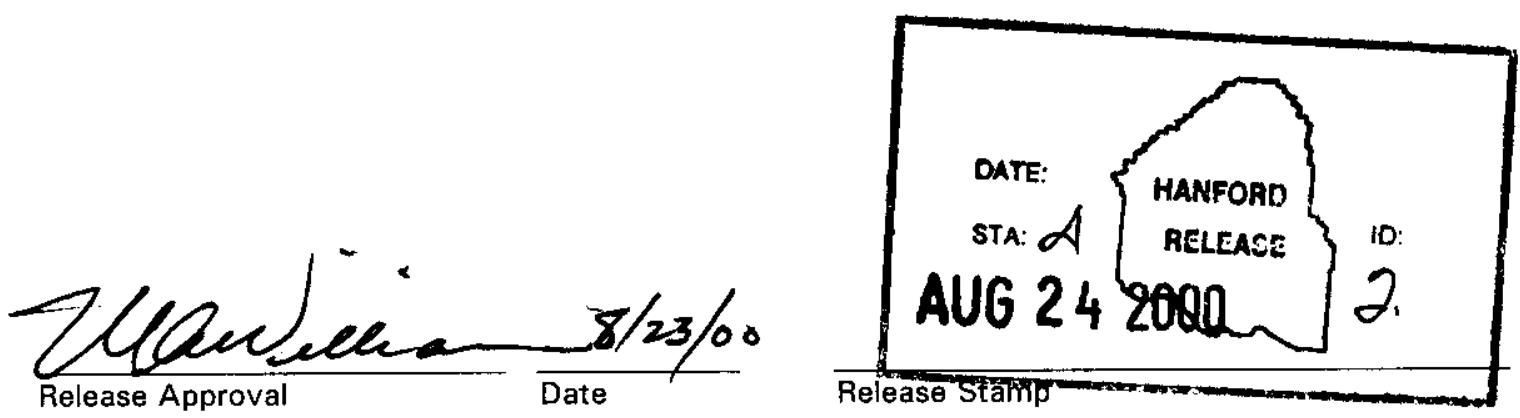
TRADEMARK DISCLAIMER

Reference herein to any specific commercial product, process, or service by trade name, trademark, manufacturer, or otherwise, does not necessarily constitute or imply its endorsement, recommendation, or favoring by the United States Government or any agency thereof or its contractors or subcontractors.

This report has been reproduced from the best available copy. Available in paper copy and microfiche.

Available electronically at $h$ ttp://www.doe.gov/bridge. Available for a processing fee to the U.S. Department of Energy and its contractors, in paper, from:

U.S. Department of Energy

Office of Scientific and Technical Information

P.O. Box 62

Oak Ridge, TN 37831-0062

phone: $865-576-8401$

fax: 865-576-5728

email: reports@adonis.osti.gov(423) 576-8401

Available for sale to the public, in paper, from:

U.S. Department of Commerce

National Technical Information Service

5285 Port Royal Road

Springfield, VA 22161

phone: 800-553-6847

fax: 703-605-6900

email: orders@ntis.fedworld.gov

online ordering: http:/www.ntis.gov/ordering.htm

Total Pages: $\quad \underline{9}$ 
(2) Title

Plan for the Characterization of K Basin Spent Nuclear Fuel and Sludge (OCRWM)

CHANGE CONTROL RECORD

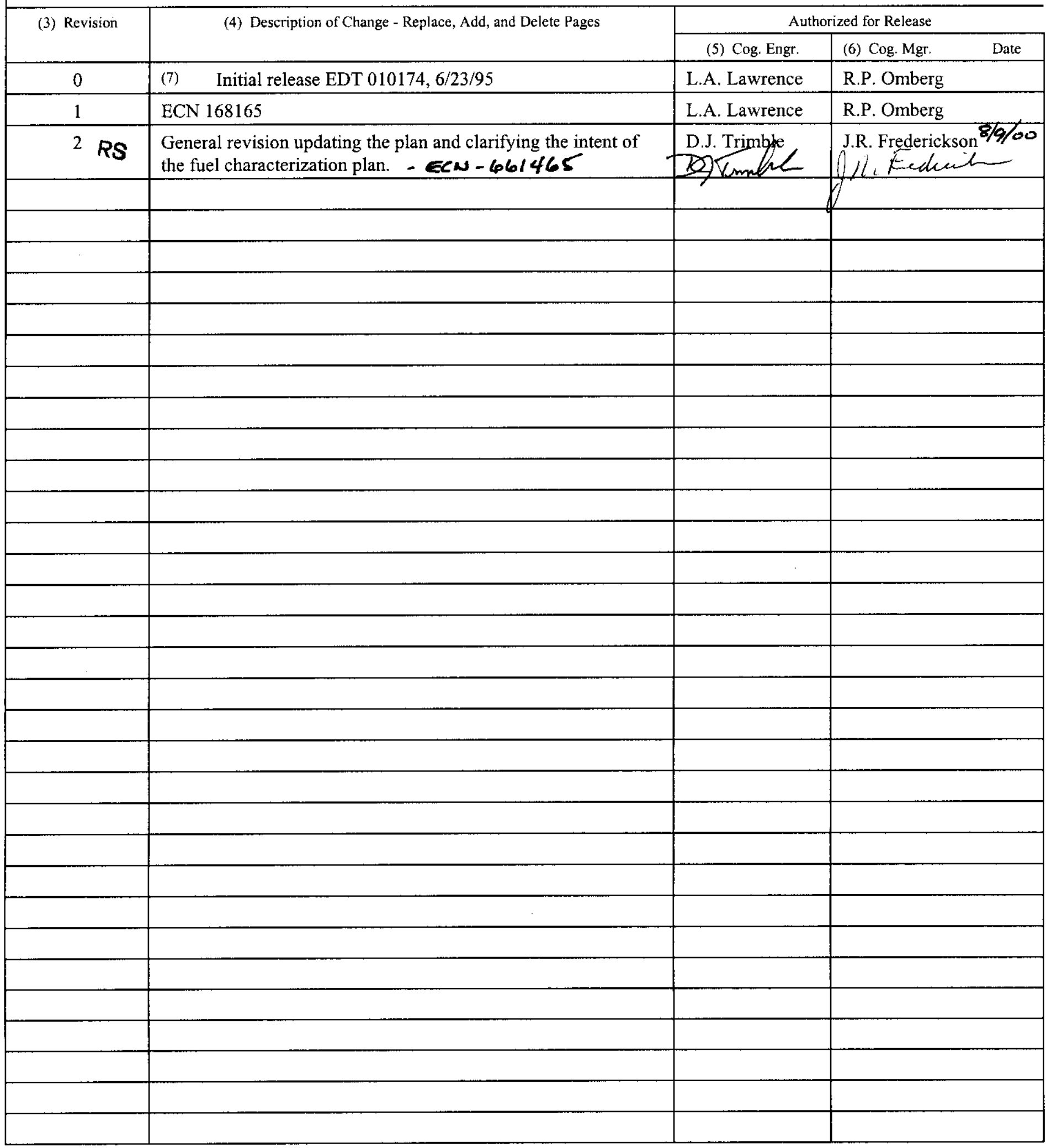


HNF-SD-SNF-PLN-007, Rev. 2

\section{Table of Contents}

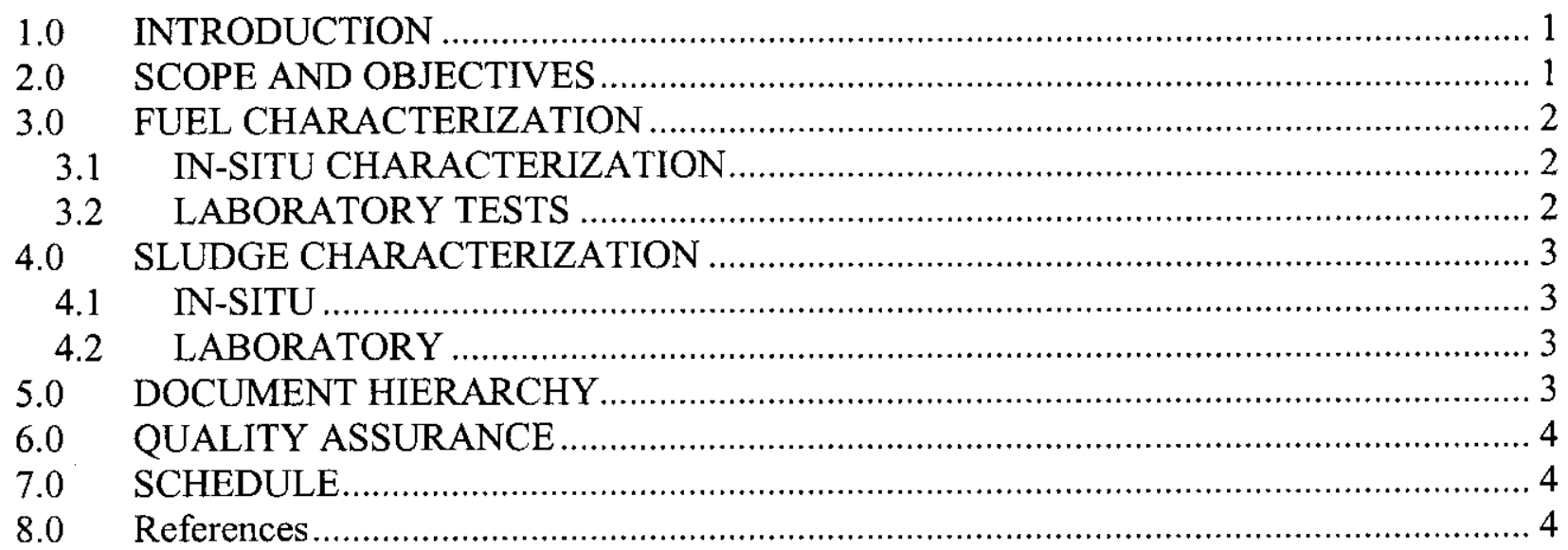

\section{List of Tables}

Table 1. Document Hierarchy for Characterization.

4

\section{List of Acronyms}

DQO Data Quality Objective

FY Fiscal Year

MCO Multi-Canister Overpack

PMP Program Management Plan

PNNL Pacific Northwest National Laboratory

SAP Sampling and Analysis Plan

SNF Spent Nuclear Fuel 
HNF-SD-SNF-PLN-007, Rev. 2

\section{PLAN FOR CHARACTERIZATION OF K BASIN SPENT NUCLEAR FUEL AND SLUDGE (OCRWM)}

\section{$1.0 \quad$ INTRODUCTION}

This is an update of the plan for the characterization of spent nuclear fuel (SNF) and sludge stored in the Hanford $\mathrm{K}$ West and $\mathrm{K}$ East Basins. The purpose of the characterization program is to provide fuel and sludge data in support of the SNF Project in the effort to remove the fuel from the K Basins and place it into dry storage.

Characterization of the K Basin fuel and sludge was initiated in 1994 and has been guided by the characterization plans (Abrefah 1994, Lawrence 1995a, Lawrence 1995b) and the characterization program management plan (PMP) (Lawrence 1995c, Lawrence 1998, Trimble 1999).

The fuel characterization was completed in 1999. Summaries of these activities were documented by Lawrence (1999) and Suyama (1999). Lawrence (1999) is a summary report providing a road map to the detailed documentation of the fuel characterization. Suyama (1999) provides a basis for the limited characterization sample size as it relates to supporting design limits and the operational safety envelope for the SNF Project.

The continuing sludge characterization is guided by a data quality objective (DQO) (Makenas 2000) and a sampling and analysis plan (SAP) (Baker, Welsh and Makenas 2000).

The original intent of the characterization program was "to provide bounding behavior for the fuel" (Lawrence 1995a). To accomplish this objective, a fuel characterization program was planned that would provide data to augment data from the literature. The program included insitu examinations of the stored fuel and laboratory testing of individual elements and small samples of fuel (Lawrence 1995a). Some of the planned tests were scaled down or cancelled due to the changing needs of the SNF Project.

The fundamental technical basis for the process that will be used to place the $\mathrm{K}$ Basin fuel into dry storage was established by several key calculations. These calculations characterized nominal and bounding behavior of fuel in Multi-Canister Overpacks (MCOs) during processing and storage. Characterization data supported input parameters that were used for the calculations. These parameters are documented in the Project Technical Databook (Reilly 1998). Calculations and reviews used in developing the parameters describe how characterization data were used in the parameter development, e.g. statistically based, added factors of conservatism, etc.

\section{$2.0 \quad$ SCOPE AND OBJECTIVES}

This updated plan addresses the characterization of the $\mathrm{K}$ Basin fuel. Plans for the ongoing and future characterization of the K Basin sludge are addressed elsewhere (Makenas 2000, Baker, Welsh and Makenas 2000). 
HNF-SD-SNF-PLN-007, Rev. 2

The objective of this revision to the characterization plan is to define the intent of the fuel characterization as it evolved during the later stages of the characterization program and as the result of changes in the SNF Project.

\subsection{FUEL CHARACTERIZATION}

Fuel element characterization activities include two main categories: in-situ characterizations and laboratory tests.

\subsection{IN-SITU CHARACTERIZATION}

The in-situ examinations are intended to provide an understanding of the physical condition of the fuel. They include video examinations of the fuel, measurement of fuel surface coating thickness, and canister gas and liquid characterization. These activities have been satisfactorily completed and documented. Required reviews of the documentation will be completed in accordance with the PMP (Trimble 1999).

Boroscopic examinations of the fuel and sludge planned in Lawrence (1995a) were not done. The lift-and-look examinations provided adequate evaluation of a significant sample of the bottom of the fuel, and canister sludge depth characterization was accomplished using ultrasonic probe measurements. A summary of this work is found in Lawrence (1999).

\subsection{LABORATORY TESTS}

The open literature and documentation of historical government-sponsored tests contain large amounts of data on the oxidation characteristics of uranium in a range of environments. These data were used to develop bounding equations to describe the oxidation kinetics of the SNF. Testing of samples cut from typical damaged fuel material is intended to provide confirmation data for these equations. Drying tests using whole fuel elements and samples of fuel particulates and coatings are intended to provide the salient drying characteristics of the fuel, including damaged fuel.

The laboratory testing of fuel and fuel material has been satisfactorily completed, providing the required confirmatory data and the desired fuel-drying characteristics (Lawrence 1999). The hot vacuum conditioning tests and dry storage simulation tests specified in Lawrence (1995a) were not done due to changes in the SNF Project strategy and needs. Hot vacuum drying was eliminated from the fuel drying strategy, and fuel storage was adequately evaluated using computer modeling. Whole-element drying tests were added to provide data on the drying characteristics of damaged fuel elements with typical surface coatings. The resulting test program that was completed meets the data needs of the SNF Project for fuel performance characteristics.

Laboratory results will be documented and reviewed in accordance with the PMP (Trimble 1999). 
HNF-SD-SNF-PLN-007, Rev. 2

\subsection{SLUDGE CHARACTERIZATION}

Sludge characterization includes in-situ measurements of sludge depth at the various locations within the $\mathrm{K}$ Basins and the laboratory analysis of sludge samples collected at selected $\mathrm{K}$ Basin locations.

\subsection{IN-SITU}

The objective of the sludge depth measurements is to provide the data for characterizing the volume of sludge in the various locations of the $\mathrm{K}$ East and $\mathrm{K}$ West Basins.

The in-situ characterization of the K Basin sludge has been satisfactorily completed and documented.

\subsection{LABORATORY}

The objectives of the sampling and laboratory analyses are to determine the physical, chemical and radiological characteristics of the sludge in the various locations of the K Basins.

Laboratory analyses of the sludge samples are continuing. The requirements for ongoing and future analyses and sampling are found elsewhere (Makenas 2000, Baker, Welsh and Makenas 2000).

\subsection{DOCUMENT HIERARCHY}

The SNF Project and Pacific Northwest National Laboratory (PNNL) document hierarchy for the SNF Characterization activities is summarized in Table 1. The PMP defines the roles and responsibilities for the organizations involved with the characterization program (Trimble 1999).

DQOs and corresponding SAPs or strategy documents, as applicable, are prepared by the SNF Project for a specific characterization activity. The DQO process follows a logical progression of data requirements definition and identification through proposed data collection, analysis, and evaluation approaches (Lawrence 1994). All data requirements are based upon a particular problem definition and on identification of SNF Project disposal decisions the characterization data is intended to support.

Various planning documents are used to provide the detail for the characterization examinations. Selection plans provide canister choices for sampling fuel and sludge. Strategy documents provide generalized plans for the examinations of selected fuel elements. Detailed Test Plans and Test Instructions are prepared by PNNL for corresponding hot cell and laboratory examinations and by the SNF Project for their area of responsibility again in support of the appropriate DQO. SAPs provide detailed instructions to the laboratories conducting sludge characterization measurements consistent with the corresponding DQO. 
Data reports, evaluations, and interpretation of the data will likewise be prepared by the SNF Project and PNNL for that which they have primary responsibility. Joint reports will be issued where applicable.

Table 1. Document Hierarchy for Characterization.

\begin{tabular}{||l|l||}
\hline \multicolumn{1}{|c|}{ Title } & \multicolumn{1}{|c|}{ Scope } \\
\hline Program Management Plan & Defines roles and responsibilities for characterization \\
\hline Characterization Plan & $\begin{array}{l}\text { General examination requirements for material being } \\
\text { sent to a repository }\end{array}$ \\
\hline $\begin{array}{l}\text { Plan for Characterization of K Basin } \\
\text { SNF and Sludge (this document) }\end{array}$ & Specific plans to support integrated Process Strategy \\
\hline Data Quality Objectives & $\begin{array}{l}\text { Documents DQO process for specific characterization } \\
\text { activities }\end{array}$ \\
\hline $\begin{array}{l}\text { Selection and Strategy Documents, } \\
\text { Test Plans, Test Instructions, and } \\
\text { Sample Analysis Plans }\end{array}$ & $\begin{array}{l}\text { Detailed testing requirements and plans to implement } \\
\text { the corresponding DQO }\end{array}$ \\
\hline Reports & $\begin{array}{l}\text { Data reports and evaluations and interpretation of the } \\
\text { data }\end{array}$ \\
\hline
\end{tabular}

\subsection{QUALITY ASSURANCE}

The quality assurance requirements for characterization activities are found in the PMP (Trimble 1999).

\subsection{SCHEDULE}

The PNNL report on internal sludge and surface coatings (PNNL-11932) will be issued in Fical Year (FY) 2001. The independent review of fuel characterization reports will be completed in FY2002. All other fuel characterization activities have been completed.

The schedule for remaining sludge characterization activities is found in Baker, Welsh and Makenas (2000).

\subsection{REFERENCES}

Abrefah, J., 1994, Characterization Plan for Hanford Spent Nuclear Fuel, PNL-10210, Rev. 0, Pacific Northwest National Laboratories, Richland, Washington.

Baker, R.B., T.L. Welsh and B.J. Makenas, 2000, HNF-6479, Rev 0, Sampling and Analysis Plan for Sludge from the 105-K Basins to Support Transport to and Storage in T Plant, Fluor Hanford, Richland, Washington. 
DOE, 1998, Office of Civilian Radioactive Waste Management, Quality Assurance Requirements and Description, DOE/RW/0333P, U.S. Department of Energy, Washington D.C.

Lawrence, L.A., 1994, Spent Nuclear Fuels Project Characterization Data Quality Objectives Strategy, WHC-EP-0795, Duke Engineering and Systems, Richland, Washington.

Lawrence, L.A., 1995a, Plan for Characterization of K Basin Spent Nuclear Fuel and Sludge, WHC-SD-SNF-PLN-007, Rev. 1, Duke Engineering and Systems, Richland, Washington.

Lawrence, L.A., 1995b, Plan for Characterization of K Basin Spent Nuclear Fuel and Sludge, WHC-SD-SNF-PLN-007, Rev. 0, Duke Engineering and Systems, Richland, Washington.

Lawrence, L.A., 1995c, Characterization Program Management Plan for Hanford K Basin Spent Nuclear Fuel, HNF-SD-SNF-PLN-010, Rev. 0, Duke Engineering and Systems, Richland, Washington.

Lawrence, L.A., 1998, Characterization Program Management Plan for Hanford K Basin Spent Nuclear Fuel, HNF-SD-SNF-PLN-010, Rev. 1, Duke Engineering and Systems, Richland, Washington.

Lawrence, L.A., 1999, K Basin Spent Nuclear Fuel Characterization, HNF-3534, Rev. 0, Duke Engineering and Systems, Richland, Washington.

Makenas, B.J., 2000, Data Quality Objectives for Analysis of Hanford K Basin Sludge to Support Transport To and Storage In T Plant, HNF-5345, Rev. 0, Fluor Hanford, Richland, Washington.

Reilly, M.A., 1998, Spent Nuclear Fuel Project Technical Databook, HNF-SD-SNF-TI-015, Rev. 6, Duke Engineering and Systems, Richland, Washington.

Suyama, R.M., 1999, K-Basin Fuel Characterization Program Technical Baseline Summary, SNF-5165, Rev. 0, Fluor Hanford, Richland, Washington.

Trimble, D.J., 1999, Characterization Program Management Plan for Hanford K Basin Spent Nuclear Fuel, HNF-SD-SNF-PLN-010, Rev. 2, Duke Engineering and Systems, Richland, Washington. 